\title{
Biome transition in a changing world: from indigenous grasslands to shrub-dominated communities
}

\author{
Pascale Ropars ${ }^{1,2 *}$, Élisabeth Comeau ${ }^{3}$, William G. Lee ${ }^{4}$ and Stéphane Boudreau ${ }^{2,3}$ \\ ${ }^{1}$ Chaire de recherche du Canada en biodiversité nordique and Département de biologie, chimie et géographie, Université du \\ Québec à Rimouski, 300 allée des Ursulines, Rimouski, QC, Canada, G5L 3A1 \\ ${ }^{2}$ Centre d'études nordiques, Université Laval, 2405 rue de la Terrasse, Québec, QC, Canada, G1V 0A6 \\ ${ }^{3}$ Département de biologie, Université Laval, 1045 avenue de la Médecine, Québec, QC, Canada, G1V 0A6 \\ ${ }^{4}$ Landcare Research, Private Bag 1930, Dunedin 9054, New Zealand and School of Biological Sciences, University of \\ Auckland, Private Bag 92019, Auckland 1010, New Zealand \\ *Author for correspondence (Email: pascale.ropars@uqar.ca)
}

Published online: 13 July 2018

\begin{abstract}
Shrub encroachment in grassland environments is observed in many regions worldwide. However, in New Zealand, there is no consensus on the trend and magnitude of this phenomenon, and we lack empirical data to determine what environmental variables may promote shrub invasion. Here, we present a comprehensive study evaluating shrub cover change in a tussock water catchment in eastern Otago, New Zealand. Specifically, we aim to quantify shrub cover change in the catchment between 1980 and 2015, to identify the shrub species involved and to determine the environmental variables that promote shrub cover change in the studied area. Using aerial photographic records over a 35 -year period, we found a $29 \%$ increase in shrub cover (from $10.5 \%$ in 1980 to $39.5 \%$ in 2015 - a 3.8-fold increase in 35 years). According to ground truthing, this shrub expansion was mainly associated with an increase in mānuka (Leptospermum scoparium) cover. Using model selection with Akaike Information Criterion, we found that the best model explaining shrub cover change in the studied tussock catchment included multiple environmental variables. Among these, initial shrub cover and elevation negatively impacted shrub cover increase within the study area, whereas slope had a positive influence, especially on the north- and east-facing aspects. Overall, shrub cover change was mostly observed in low-elevation gullies ( $<500$ metres elevation) with steep slopes, where mānuka is known to have optimal growth conditions. However, further shrub cover expansion may be slow as most of the available space is now restricted to poorly drained spurs at higher elevation ( $>650$ metres elevation).
\end{abstract}

Keywords aerial photographs; Glendhu State Forest; grasslands; Leptospermum scoparium; model selection; shrub expansion; topography

\section{Introduction}

Many open ecosystems worldwide have seen an increase in woody cover over the last decades (Eldridge et al. 2011; Myers-Smith et al. 2011; Naito \& Cairns 2011; Sala \& Maestre 2014). This phenomenon is observed across continents (North and South America: Van Auken 2000; Ghersa et al. 2002; Tape et al. 2006, Africa: Roques et al. 2001; Skowno et al. 2017, Eurasia: Maestre et al. 2009; Forbes et al. 2010; Hallinger et al. 2010, Australia: Hugues 2003; Fensham et al. 2005, New Zealand: Wilmshurst et al. 2004, McGlone et al. 2007), in different biomes (tundra: Tape et al. 2006; Myers-Smith et al. 2011; Ropars \& Boudreau 2012, savannas: Jeltsch et al. 1997; Ansley et al. 2001, desert grasslands: Goslee et al. 2003; Gibbens et al. 2005, mesic grasslands: Lett \& Knapp 2005) and is driven by the increased recruitment, growth and survival of a wide array of shrub and tree taxa (Cupressaceae, e.g. Juniperus sp.: McKinley \& Blair 2008; Hallinger et al. 2010, Betulaceae, e.g. Alnus sp., Betula sp., Salix sp.: Ropars \& Boudreau 2012; Myers-Smith et al. 2011, Fabaceae, e.g. Dichrostachys sp., Prosopis sp., Acacia sp.: Jeltsch et al. 1997; Van Auken 2000; Roques et al. 2001, Zygophyllaceae, e.g. Larrea sp.: Peters et al. 2006).

Even if they occur naturally worldwide, grasslands have often been created and maintained by human activities such as prescribed burning and pastoralism. In New Zealand for instance, the woody component of these ecosystems have been removed in many places by successive fires and mammalian grazing, and resulted in the transition of many tall-tussock grasslands to short-tussock grasslands dominated by less palatable native species and a larger exotic component (Walker et al.2009). These montane grasslands are therefore indigenous but induced, which creates challenges and continuing debates, particularly regarding the management of their woody component, its impacts on indigenous biodiversity and the relevant conservation objectives (Calder et al. 1992; Walker et al. 2004; Mark \& Dickinson 2008; Walker et al. 2014a). The widespread cessation of burning and pastoralism in recent decades, following the setting aside of more areas for the protection of biodiversity, have promoted the return of woody species in these grasslands through natural succession, a phenomenon probably assisted by milder climate conditions in recent decades (e.g. Campbell Island; Wilmshurst et al. 2004).

In addition to the increase in woodiness occurring during natural succession, shrub expansion is often associated with changes in disturbance regimes and/or environmental conditions (Eldridge et al. 2011; Naito \& Cairns 2011; D'Odorico et al. 2012). For example, shrub expansion has been accelerated by fire control in southwestern North America (Van Auken 2000) and Africa (Roques et al. 2001). Along 
with reduction in fire frequency and amplitude, livestock grazing can contribute to shrub expansion by altering grass and herbaceous species biomass (Van Auken 2000) and by lowering available grass fuels for fire (Naito \& Cairns 2011). Herbivory on shrubs is also known to lower their performance in different environments and to limit their expansion (reindeers: Olofsson et al. 2009; Plante et al. 2014; ptarmigans: Christie et al. 2014, antelopes: Augustine \& McNaughton 2004, prairie dogs: Weltzin et al. 1997). At higher latitudes (i.e. arctic and subarctic regions), improved climatic conditions, especially in summer, are generally cited as the main driver of shrub expansion (Naito \& Cairns 2011; Myers-Smith et al. 2015; Ropars et al. 2015). Other processes involved in shrub expansion include increase in $\mathrm{CO}_{2}$ levels (Morgan et al. 2007) and change in rainfall regimes (Fensham et al. 2005).

One of the main concerns over the transition of grassland to shrubland arises from the associated changes in ecosystem goods and services, often with serious implications for local pastoral economies. Increase in shrub cover is, for example, associated with lower plant species richness in grasslands and savannas worldwide (Knapp et al. 2008; Eldridge et al. 2011; Ratajczak et al. 2012) and with the decline in lichen abundance in Arctic regions (Elmendorf et al. 2012). The loss of grass cover and the increase in bare soil due to shading by shrubs typically leads to the intensification of water and wind erosion and to the loss of nutrient-rich soil particles (Parsons et al. 1996; Schlesinger et al. 1999; Wainwright et al. 2000; Li et al. 2007, 2008). The transition from grasslands to woody vegetation is also known to reduce water yield, causing or intensifying water shortage in many regions of the world (Farley et al. 2005), decreasing albedo (Chapin et al. 2005) and altering surface energy exchange and soil temperature (Liston et al. 2002; Pomeroy et al. 2006; Marsh et al. 2010). Maintaining a mosaic of grasslands and shrublands at the landscape scale can however sustain complementary biodiversity (Walker et al. 2014b).

Grasslands management, particularly regarding their woody component and its impacts on indigenous biodiversity and ecosystem services, generates continuing debate as many grasslands, even if indigenous, have originated and been maintained in the landscape through anthropogenic activities (Calder et al. 1992; Mark \& Dickinson 2008; Walker et al. 2014a). The decrease in grassland cover at the global scale has accelerated since the early 1900s (Archer 2010), and is believed to affect more than two billion people worldwide by reducing rangelands available for livestock (Adeel 2008). In the United States and southern Africa, for instance, 330 million and 13 million hectares of grasslands and savannas are undergoing shrub expansion, respectively (Trollope et al. 1989; Pacala et al. 2001; Knapp et al. 2008). In New Zealand, indigenous grasslands have shrunk by $40 \%$ since 1840 (Weeks et al. 2013) due to the expansion and intensification of agriculture. Moreover, the increasing demand for lumber in many countries has led to extensive forestry plantations, further impacting grassland cover.

Shrub expansion into grasslands has generated great scientific interest over the past decades, but the actual trend and magnitude of this phenomenon is still under debate in New Zealand (Mark \& Dickinson 2003). Here, we present a comprehensive study evaluating shrub cover change in a tussock water catchment in eastern Otago, New Zealand, using aerial photographic records over a 35-year period. Specifically, we aim (1) to quantify shrub cover change in the catchment between 1980 and 2015, (2) to identify the shrub species responsible for this phenomenon and (3) to identify the environmental variables that promote shrub cover change in the studied area.

\section{Methods}

\section{Study site}

The study area is a 216-ha water catchment located in the former Glendhu State Forest in the upper Waipori basin in the Lammerlaw Range, $60 \mathrm{~km}$ west of Dunedin, eastern Otago, New Zealand (Fig. 1). The catchment is north-facing, underlain by schist bedrock, and has rolling-to-steep topography supporting acidic brown soils. With an elevational range of 480-690 m a.s.1., the area is below the regional treeline (c. $850 \mathrm{~m}$ ) and was covered by forests and tall shrublands of Lophozonia menziesii (Hook.f.) Heenan \& Smissen, Prumnopitys taxifolia (Sol. ex D.Don) de Laub., Podocarpus spp., Halocarpus bidwillii(Kirk) Quinn and Phyllocladus alpinus Hook.f. in pre-human times (McGlone \& Wilmshurst 1999; McGlone 2001; Leathwick et al. 2004). The frequent Polynesian fires destroyed the forest and induced an indigenous tall-tussock grassland from the $13^{\text {th }}$ century, whereas the European pastoralism fostered the opening of the landscape, converting this tall-tussock canopy into pastures (McGlone \& Wilmhurst 1999). Narrow-leaved snow tussock (Chionochloa rigida (Raoul) Zotov ssp. rigida) is the dominant herbaceous species, while C. rubra (Zotov) ssp. cuprea (Connor) is observed on wetter soils. Inter-tussock areas support the small tussocks Poa colensoi (Hook f.) and Festuca novae-zelandiae (Hack. Cockayne) among now an extensive cover of introduced grasses including Agrostis capillaris L. and Anthoxanthum odoratum L. Mānuka, Leptospermum scoparium (JR Forst \& G Forst), is the most widely distributed shrub species, but Coprosma dumosa (Cheeseman) G.T. Jane

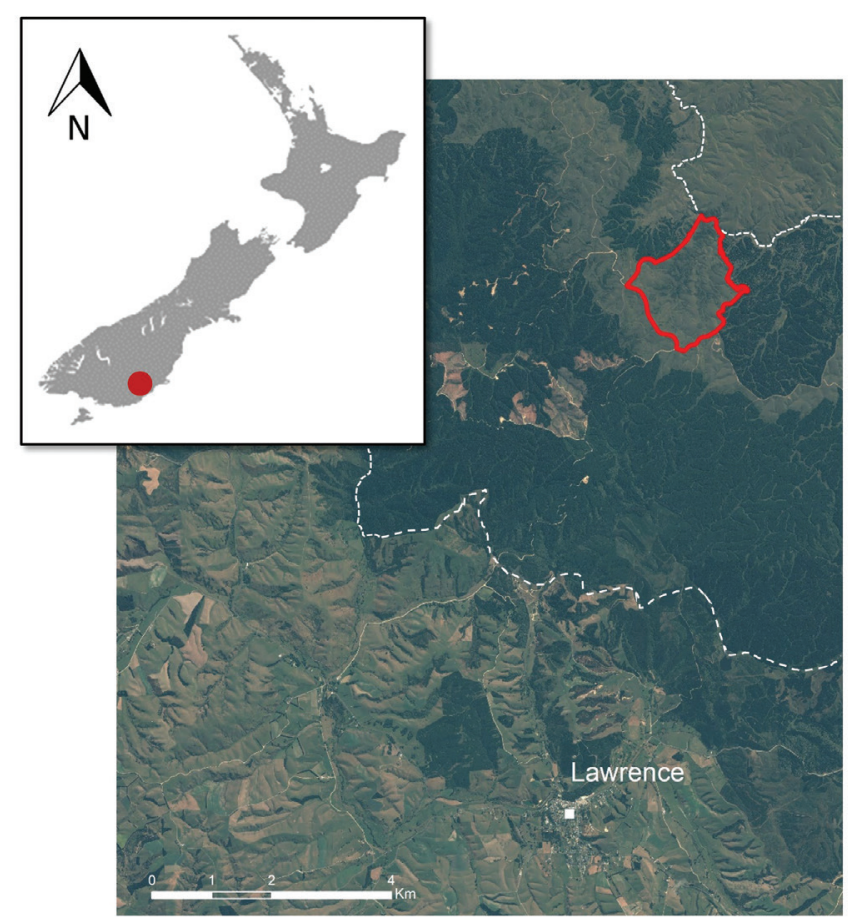

Figure 1. Study site location on New Zealand's South Island. The studied water catchment (in red) is part of the Glendhu State Forest (delimited with a white dotted line). 
and Ozothamnus leptophyllus (G. Forst.) Breitw \& JM Ward are also found in the grassland. Amore detailed site description can be found in Fahey \& Watson (1991) and Fahey \& Payne (2015).

The Glendhu region has a long fire history, with the first records dating back from the $12000-9580 \mathrm{yr}$ BP period. From 9580 to c. $1000 \mathrm{yr} \mathrm{BP}$, fires appear infrequent, with only 4 major fires recorded. Pollen analyses showed an important reduction in tree species following these events, whereas shrubs and grasses became more abundant. Fire regime changed markedly in the $13^{\text {th }}$ century, with the arrival of Māori. During this period, it is thought that the catchment could have been burnt as much as several times a decade. Fires frequency increased also with the European settlements (c. 1860) in the region, but then decreased afterward (McGlone \& Wilmshurst 1999).

The catchment of interest is part of the Glendhu pairedcatchment watershed experiment established in 1979 (O'Loughlin et al. 1984). It has been designed to assess the effect of the afforestation of tussock grassland on water yield (for a recent account see Fahey \& Payne 2017), which is of particular concern in eastern grasslands used for urban water supply. One of the two experimental catchments was planted with Pinus radiata (D. Don) while the second one (our study site) served as control and was fenced in 1982 and left as a tussock grassland. The tussock catchment was grazed by sheep until 1982, lightly grazed from 1982 to 2002 (< 1 sheep $\mathrm{ha}^{-1}$ ) and left ungrazed afterwards, following sheep exclusion (Fahey \& Payne 2015). Feral deer (Cervus elaphus) and hares (Lepus europaeus) have been seen in the catchment, but grazing intensity is likely low.

Climate conditions, as summarised by Fahey \& Payne (2017), are derived from a combination of local records and data from a meteorological station located at Lake Mahinerangi, $20 \mathrm{~km}$ away from the study area. Mean annual precipitation is approximately $1300 \mathrm{~mm}$ with little seasonality, while snow falls between 10-20 days per year. Mean annual temperature is c. $8.6^{\circ} \mathrm{C}$, with the highest and lowest mean monthly temperatures recorded in January $\left(12.7^{\circ} \mathrm{C}\right)$ and July $\left(3.6^{\circ} \mathrm{C}\right)$, respectively.

\section{Shrub cover change}

To quantify the change in indigenous woody cover in the tussock catchment, we conducted a comparative analysis using a mosaic of vertical aerial photographs from 1980 and 2015. The 1980 mosaic consisted of four aerial photographs of unknown scale and resolution. The 2015 mosaic consisted of two aerial photographs taken in winter that have a $0.4 \mathrm{~m}$ resolution. Hard copies of these photographs were scanned, digitised, projected in the New Zealand Transverse Mercator, resampled at $1 \mathrm{~m}$ resolution and orthorectified with ERDAS Imagine version 2011 (Hexagon Geospatial). The spatial lag, or spatial difference, between the 1980 and 2015 aerial photos is $<2 \mathrm{~m}$. Hereafter, both images will be referred to as ortho-photos.

The study area on each set of ortho-photos was delimited with ArcGIS (v.10, ESRI), and a grid consisting of $144 \mathrm{~m}^{2}$ cells $(12 \times 12 \mathrm{~m})$ was overlaid (following the methodology in Ropars \& Boudreau 2012). Shrub-covered areas on the ortho-photos can be detected visually by their darker shade and distinct foliage texture. Shrub cover was estimated within each cell $(n=15 \quad 154)$ and assigned to one of the following cover classes: $0 \%$ (1), 1-25\% (2), 26-50\% (3), 51-75\% (4) and $76-100 \%$ (5). Total shrub cover in the catchment was calculated by averaging the median value of the cover class assigned to each cell. Shrub cover change was calculated as the shrub cover difference between 2015 and 1980. We used a Digital Elevation Model (resolution $25 \mathrm{~m}$, downloaded from http://koordinates.com) to extract the aspect (categorical: N, E, $\mathrm{S}, \mathrm{W}$ ), slope (in degrees) and elevation (in m a.s.l.) of each cell.

\section{Ground truthing}

Prior to the field season, the catchment was subdivided using a 5'-latitude $\times 5$ '-longitude grid. In each of the 30 resulting cells, we identified one site in each of the following categories, when possible: north-, south-, east-, west-facing slopes, and hilltops (Fig. 3), with no more than 5 sites in each cell. Overall, 82 quadrats (north $=16$, south $=11$, east $=15$, west $=14$, hilltop $=26$ ) were selected and visited in February 2012 in order to characterize the shrub cover. At any given sampling location, each shrub individual (or patch) was identified to the species level and its canopy cover and height were measured. The canopy cover was obtained by the following formula:

$$
\text { Canopy Cover }=\frac{d 1}{2} \times \frac{d 2}{2} \times \pi
$$

where $d 1$ and $d 2$ are two perpendicular diameters of an individual. The area covered by shrubs was summed to obtain total shrub cover and shrub cover per species for each quadrat.

\section{Statistical analysis}

Using the classified ortho-images from the tussock catchment, we assessed the effect of elevation, aspect, slope and initial shrub cover (i.e. in 1980) on shrub cover change between 1980 and 2015. Because the dependent variable is categorical and ordinal, we used a cumulative link model (clm in package ordinal, Christensen 2015) - these fit binary and proportional odds ordinal regression using maximum likelihood estimation. In our model, aspect was defined as a factor with four levels consisting of $90^{\circ}$ around the cardinal points (north, east, south, and west). The variation inflation factor (VIF) for each of the selected variables was verified and were all $<10$. As a result, no variables were excluded from the analyses. We used a $2 \%$ subset ( 303 cells) of the original dataset ( 15154 cells) to override autocorrelation issues, which can lead to false positive correlation (Dale \& Fortin 2002).

We built ecologically relevant statistical models that could explain shrub cover change between 1980 and 2015 in the study area using the environmental variables described above (see Table 1). To determine the most plausible model(s), we used model selection based on Akaike's information criterion corrected for small sample size (AICc; Sugiura 1978). AICc considers the fitting quality and the number of variables included in each competing model and ranks them in terms of loss of information. The best model, i.e. the one having the lowest AICc value, is therefore the one for which the loss of information is minimal (Mazerolle 2006). Using the aictab function of the AICcmodavg package (Mazerolle 2014), we calculated the AICc for each of the 10 competing models. The aictab function also calculates delta AICc ( $\triangle \mathrm{AICc}), \mathrm{AICc}$ weight (wAICc) and the cumulative AICc weight. The $\Delta \mathrm{AICc}$ is calculated as the difference between the AICc of one model and the lowest AICc value, the best model therefore having a $\triangle$ AICc equal to 0 . The WAICc is the likelihood of a given model to be the best among a set of competing models (Johnson \& Omland 2004), whereas the cumulative AICc weight corresponds to the WAICc of one model plus the wAICc values and all better models. Burnham \& Anderson (2002) suggest basing conclusions on the multimodel inference if wAICc of the best model $<0.90$. This approach allows us to compute 
Table 1. Akaike's information criterion corrected for small sample size (AICc), differences ( $\triangle \mathrm{AICc}$ ), weight (wAICc), cumulative weight (cumul. wAICc) and number of parameters (K) from the linear mixed models explaining shrub cover increase between 1980 and 2015 in the Glendhu tussock water catchment, east Otago, New Zealand. 'Shrub1980' refers to the shrub cover evaluated from the 1980 aerial photo.

\begin{tabular}{lccccc}
\hline Models & K & AICc & AAICc & wAICc & Cumul. wAICc \\
\hline Shrub1980+Elevation+Aspect+Slope & 11 & 731.58 & 0.00 & 0.85 & 0.85 \\
Elevation+Aspect+Slope & 10 & 735.04 & 3.46 & 0.15 & 1.00 \\
Shrub1980+Slope & 7 & 744.30 & 12.72 & 0.00 & 1.00 \\
Slope & 6 & 745.78 & 14.20 & 0.00 & 1.00 \\
Elevation+Aspect & 9 & 768.31 & 36.73 & 0.00 & 1.00 \\
Shrub1980+ Elevation+Aspect & 10 & 769.50 & 37.92 & 0.00 & 1.00 \\
Aspect & 8 & 776.78 & 45.20 & 0.00 & 1.00 \\
Shrub1980+Aspect & 9 & 778.67 & 47.09 & 0.00 & 1.00 \\
Elevation & 6 & 781.42 & 49.84 & 0.00 & 1.00 \\
Shrub1980 & 6 & 788.33 & 56.76 & 0.00 & \\
\end{tabular}

a) 1980 aerial picture and shrub cover evaluation
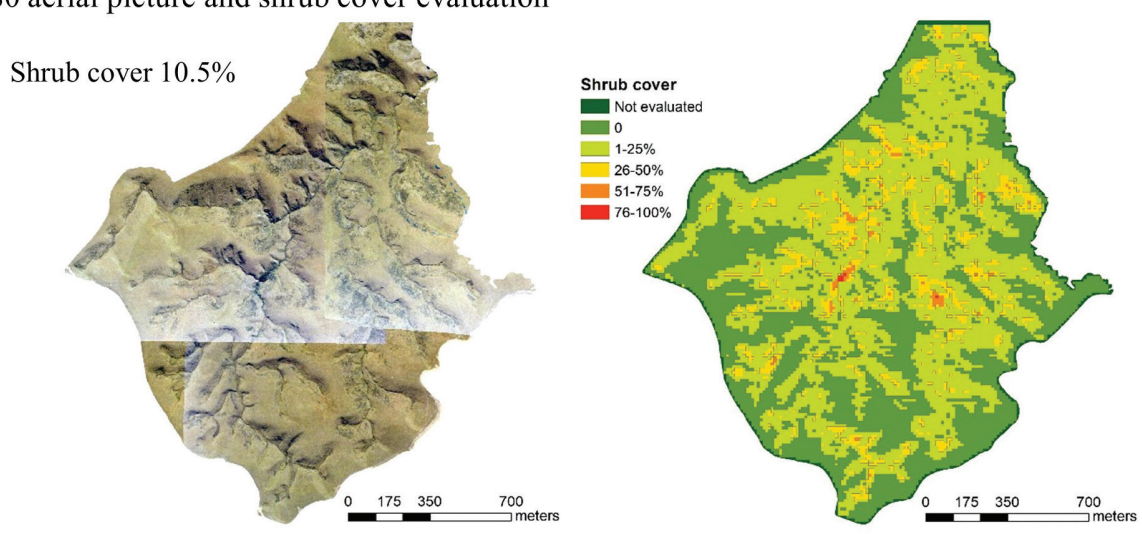

b) 2015 aerial picture and shrub cover evaluation
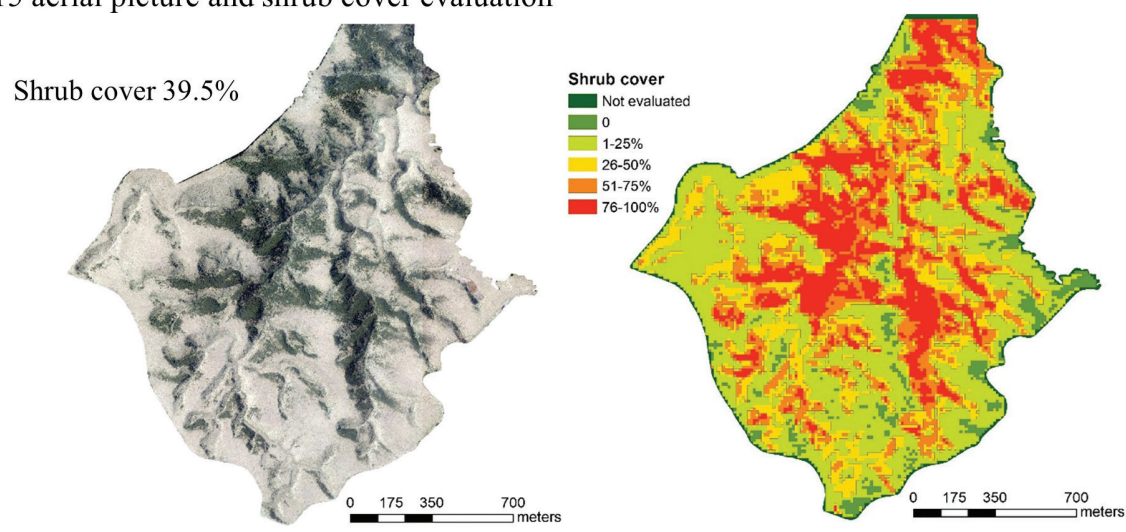

Figure 2. Shrub cover change in the Glendhu water catchment, east Otago, New Zealand, from 1980 to 2015. Figures a) and b) show the aerial picture and the shrub cover as evaluated from this picture for 1980 and 2009, respectively; and c) shows shrub cover increase from 1980 to 2015 in shrub cover classes.

c) Shrub encroachment from 1980 to 2015
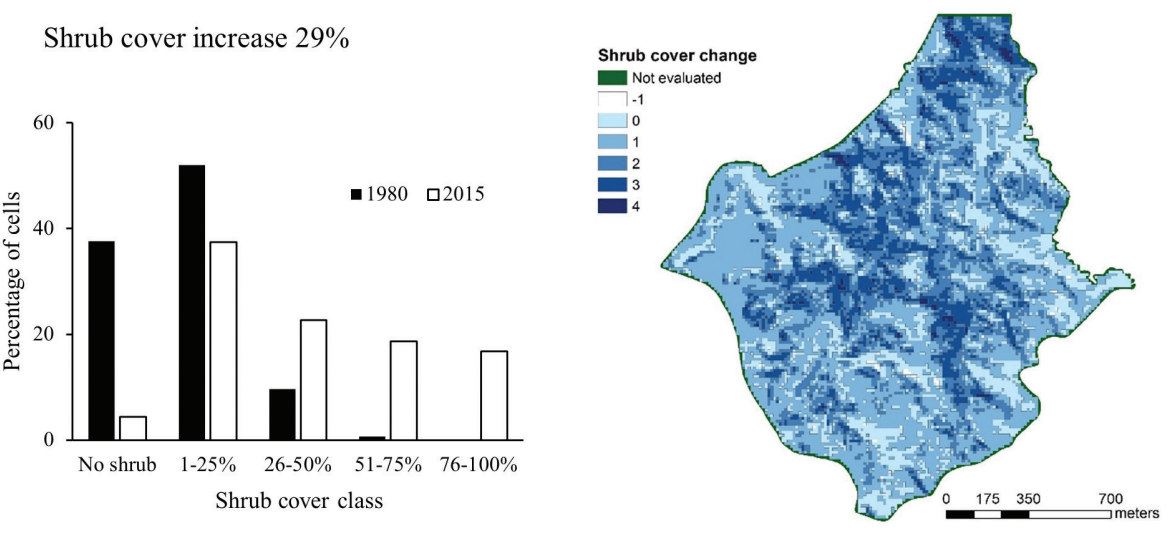

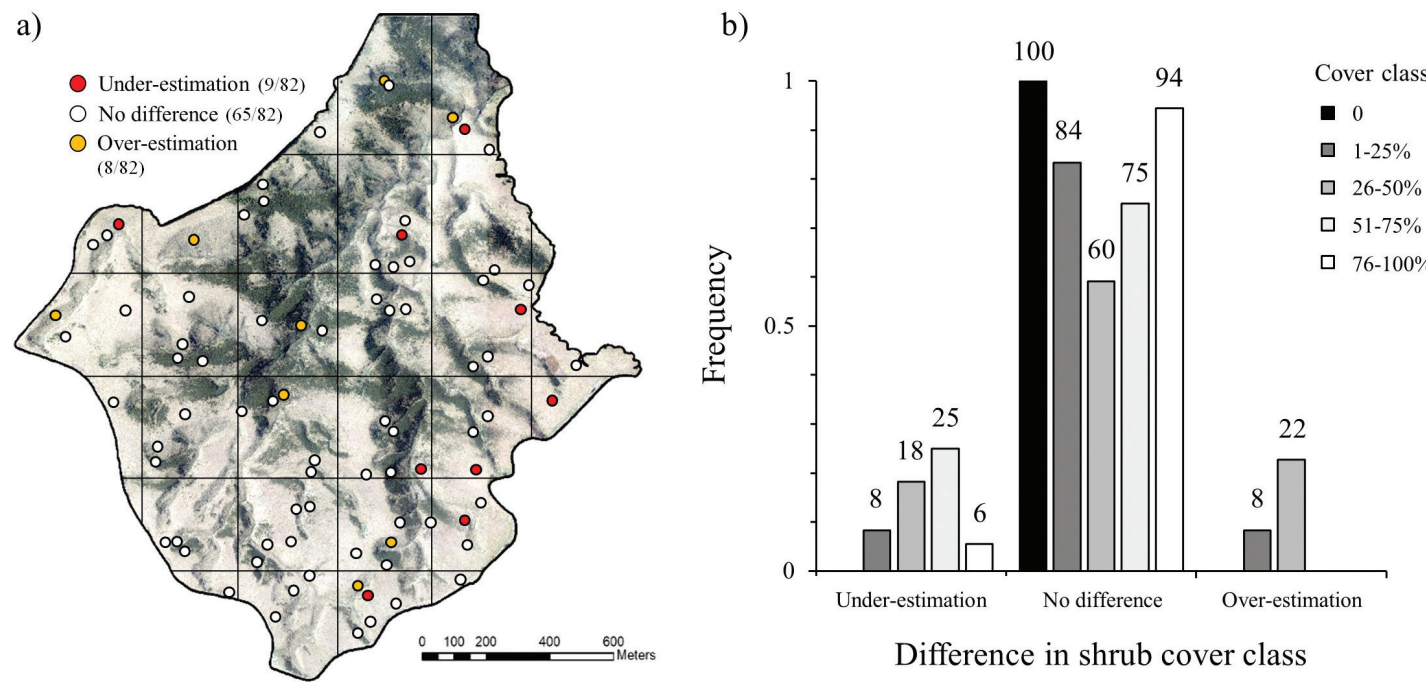

Figure 3. Discrepancy between shrub cover class evaluation based on aerial image analysis and shrub cover measurement in the field (ground truthing). The spatial distribution of the discrepancy is shown on the map (a), where dots represent quadrats ( $\mathrm{n}=82)$ for which there was no difference (white), under (red) and over-estimation (yellow) of the shrub cover between the aerial image evaluation and the measurement in the field, respectively. The frequency plot (b) shows the percentage of quadrats for which there was an under, equal and over-estimation of the shrub cover based on ground truthing, for each of the cover classes.

a weighted average of estimates of the variables of interest instead of relying solely on the estimates of the best model. Using the modavg function of the AICcmodavg package, we obtain the model-averaged estimate of the parameters, the unconditional standard error and the $95 \%$ confidence interval. We can conclude that one variable has an effect on shrub cover change when the confidence interval excludes 0 .

The effect of elevation and slope on the cover of the four main shrub species was evaluated through generalized linear models (GLM). The dependent variables were tested for normality using the Shapiro-Wilk test and appropriate distribution was assigned to the variables for which we rejected the null hypothesis (Poisson distribution for all shrub species). We used one-way analysis of variance (ANOVA) to test for the effect of aspect on the cover of the 4 main shrub species. If significant differences were found, Tukey multiple comparison tests were used to determine significant differences between aspects. We also calculated the Moran's index to assess any possible autocorrelation in shrub cover change between 1980 and 2015. All analyses were conducted in the R Environment (R Development Core Team, version 3.4.1).

\section{Results}

\section{Shrub cover change}

The aerial images analysis showed important shrub cover change in the tussock catchment between 1980 and 2015 (Fig. 2). Shrub cover was estimated at $39.5 \%$ in 2015 , an increase of $29 \%$ when compared to $1980(10.5 \%)$, indicating that the area covered by shrub increased 3.8-fold in 35 years. In 1980, most of the cells $(90 \%)$ fell into the first two cover classes (no shrub $=38 \%$ and $1-25 \%$ shrub cover $=52 \%$ ), whereas in 2015 the majority (59\%) of the cells had a shrub cover $>25 \%$ (Fig. 2c). Overall, an increase in shrub cover was recorded for $80 \%$ of the analysed cells (12 217/15 154). However, the spatial distribution of shrub cover change was highly clustered
(Moran's Index $=0.703$, z-score $=121.690, p$-value $<0.01$ ), most occurring in gullies.

\section{Ground truthing}

Overall, ground truthing corroborates the results of the 2015 image analysis and suggests that there was neither general nor spatial distribution bias for shrub cover estimation (Fig. 3a, b). Shrub cover measured in the field was in concordance with the cover class assigned on the 2015 orthophoto for 65 out of 82 quadrats $(79 \%$, Fig. 3). For the remaining 17 quadrats, we observed a difference of one cover class, with shrub cover being under- and overestimated 9 and 8 times, respectively.

Mānuka (L. scoparium) was the most abundant species recorded in the catchment, being recorded in 47 out of 82 quadrats. Covering $27.8 \%$ of the surveyed area (82 quadrats $X$ $25 \mathrm{~m}^{2}$ ), its cover was significantly higher on north- and eastfacing slopes (Tukey multiple comparison, p-values $<0.01$; Fig. 4) as well as on steeper slopes $\left(\mathrm{F}_{1,79}=5.351, \mathrm{P}=0.023\right)$, where it forms extensive patches largely exceeding the surveyed quadrats. Other shrub species found in the tussock catchment in 2012 were Coprosma dumosa, Ozothamnus leptophyllus, Hebe odora (Hook.f.) Cockayne and Dracophyllum longifolium (JR Forst \& G Forst.), which covered on average $7.6 \%, 2.6 \%, 0.9 \%$ and $0.2 \%$ of the surveyed area, respectively. When compared to mānuka, these species were rarely encountered on northand east-facing slopes, where their average cover was $5.0 \%$, $0.4 \%, 0.5 \%$ and $0.1 \%$, respectively. No effect of slope, aspect and elevation was found for C. dumosa, O. leptophyllus and H. odora. As it was recorded in 5 sites only, these relationships were not tested for $D$. longifolium.

\section{Candidate models to explain shrub cover change}

Given the 10 models we built for model selection using Akaike's Information Criterion(AICc), we found that the model including all environmental variables was the most plausible one (Table 1). This model was 5.7 times more plausible than the second-best model (evidence ratio: $\mathrm{wAICc}_{\text {best model }} / \mathrm{WAICc}_{2 \text { nd }}$ 


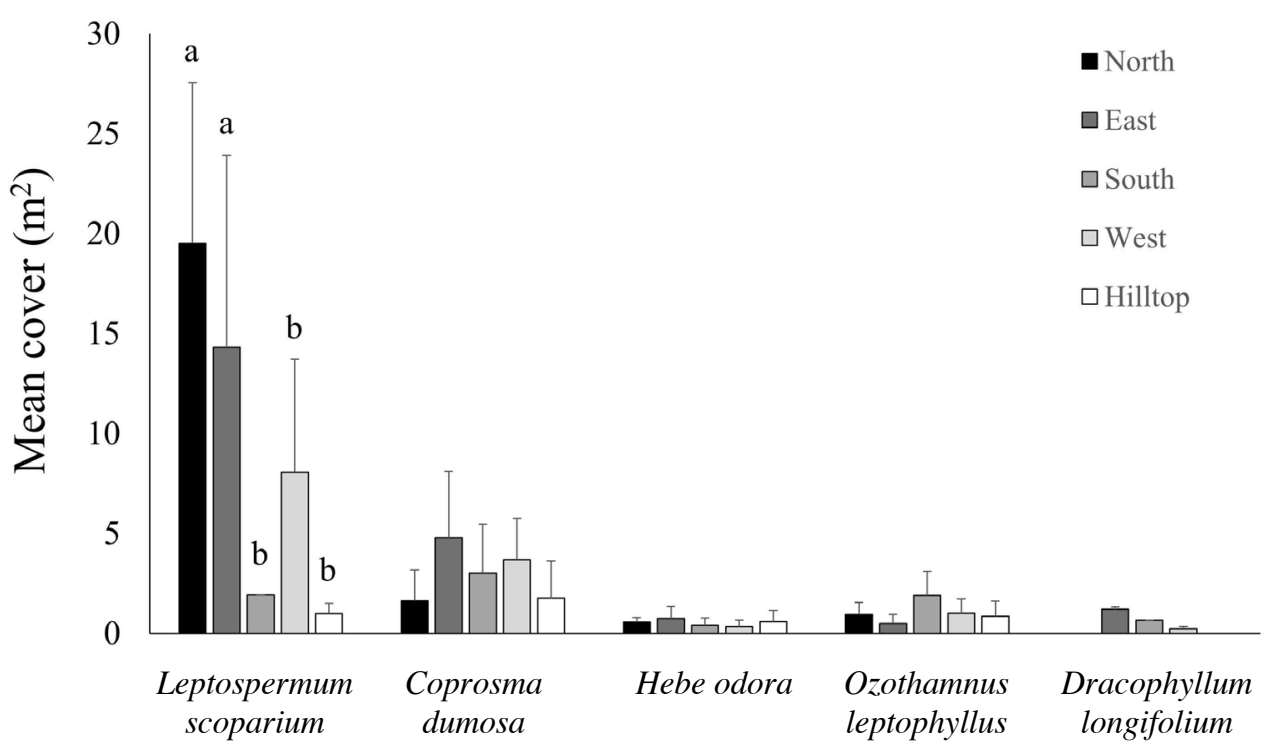

Figure 4. Mean shrub cover by aspect as measured in the ground truthing sample plots $(\mathrm{n}=82$, dimensions $=5 \times 5 \mathrm{~m})$, Glendhu, east Otago, New Zealand. Significant differences in Leptospermum scoparium cover are represented by different letters. No significant differences were found within any other species.

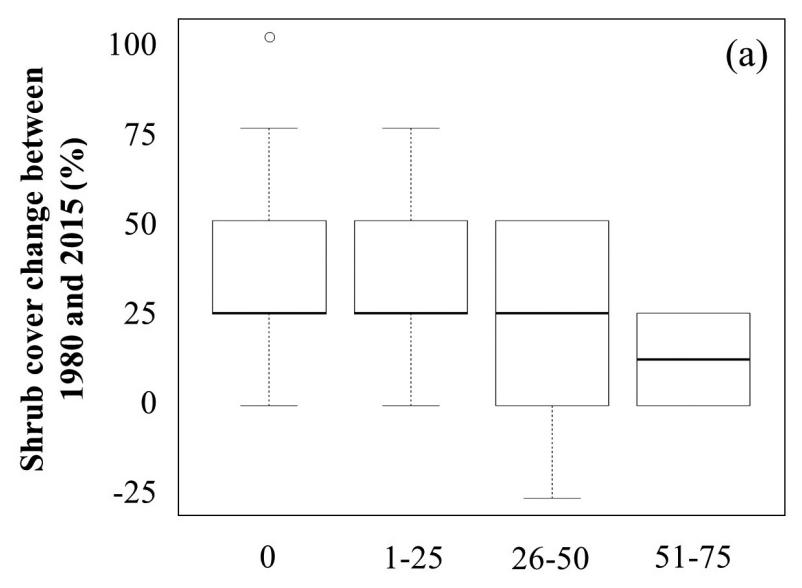

Shrub cover in $1980(\%)$

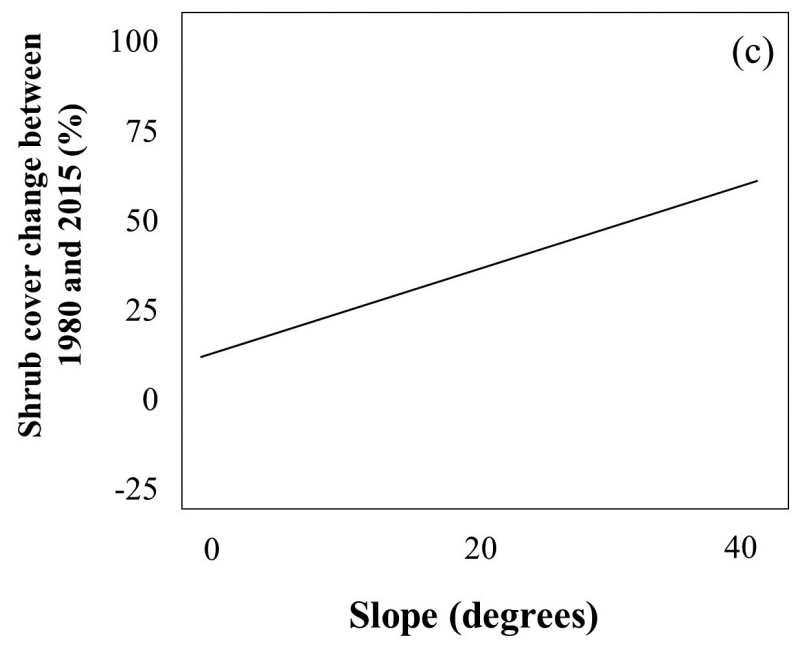

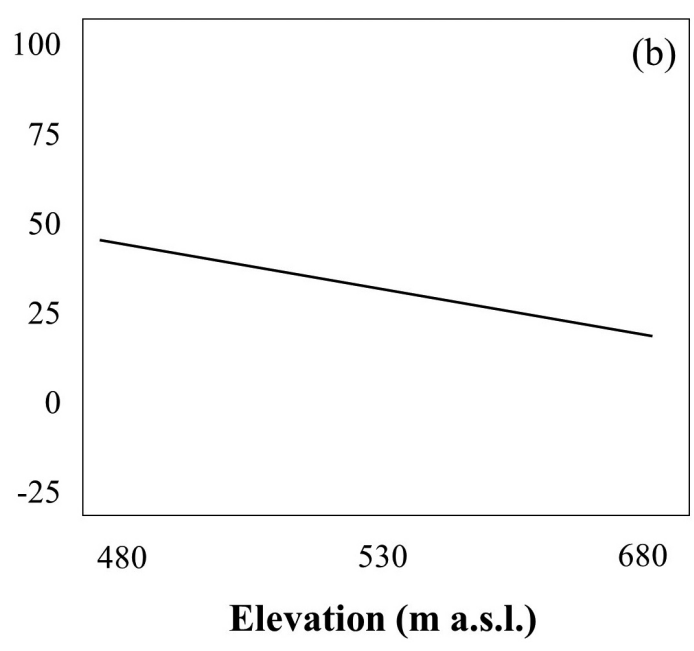

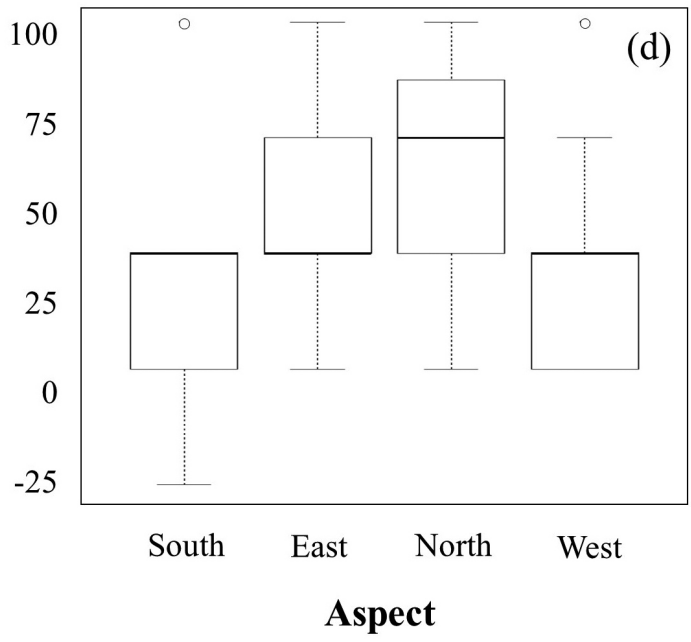

Figure 5. Influence of shrub cover in 1980 (a), elevation (b), slope (c) and aspect (d) on shrub cover change between 1980 and 2015 (shrub cover in 2015 - shrub cover in 1980) in the Glendhu tussock water catchment, east Otago, New Zealand. 
best model: 0.85/0.15). However, since it had a wAICc $<0.90$, we calculated the model-averaged estimate of the 4 variables included in all plausible models, as suggested by Burnham \& Anderson (2002). Among them, shrub cover in 1980 (estimate: -0.57 , unconditional SE: $0.18,95 \%$ confidence interval: $-0.93,-0.22$ ) and elevation (estimate: -1.91 , unconditional SE: $0.54,95 \%$ confidence interval: $-2.98,0.84$ ) negatively impacted shrub cover increase over the 35yr-period (Fig. 5a and b), whereas slope (estimate: 4.64, unconditional SE: 0.77 , $95 \%$ confidence interval: $3.12,6.15)$ had a positive effect on shrub cover change (Fig. 5d). Finally, shrub cover change was greater on north (estimate: 1.45 , unconditional SE: $0.39,95 \%$ confidence interval: $0.68,2.22$ ) and east-facing (estimate: 1.71 , unconditional SE: $0.39,95 \%$ confidence interval: $0.94,2.48$ ) slopes (Fig. 5c), when compared to cover change on slopes facing south and west (Fig. 5d).

\section{Discussion}

Our results indicate important shrub cover change in indigenous tussock grassland of eastern Otago (New Zealand) following a change in disturbance regime, mainly reduced grazing and fire frequency. During the 35-year period covered by our analysis, shrub cover increased almost 4-fold, which corroborates the findings of other studies in grassland ecosystems (Roger \& Leathwick 1996; Price \& Morgan 2009, but see Mark \& Dickinson 2003).

\section{Conversion from grasslands to shrub-dominated communities}

The invasion of grasslands by shrub species has been observed in multiple regions (Australia: Fensham et al. 2005; Price \& Morgan 2009, Africa: Roques et al. 2001, United States: Van Auken 2000; Tape et al. 2006, Mediterranean region: Maestre et al. 2009) and is primarily caused by changes in disturbance regimes (herbivory, fires, climate, land-use). While evidence of shrub expansion has been found in some New Zealand grasslands (Roger \& Leathwick 1996; Wilmshurst et al. 2004; Walker et al. 2009), this appears not to be the case in the Black Rock Reserve (Mark \& Dickinson 2003), where little evidence of shrub invasion in the absence of grazing was found over the 1972-2002 period. This result contrasts with our findings, which show a clear increase in the extent of woody cover from 1980. Such differences between the two studies can at least partly be explained by their scale and location. The monitored transects at Black Rock Reserve recorded plant communities located on broad, flat, poorly drained spurs, above $700 \mathrm{~m}$ a.s.l. and well away from shrub-clad gullies, where expansion may be expected. In contrast, increase in shrub cover at Glendhu was assessed at the catchment scale using aerial imagery, capturing communities on all landforms, all below $700 \mathrm{~m}$ a.s.1. Our analysis revealed a highly clustered shrub cover change, mostly centred on gullies, even if new isolated individuals might have become established over the 35-year period.

Differences in shrub species richness may also partly explain the contrasting results observed between Black Rock Reserve and Glendhu. Our ground truthing showed that the shrub cover increase was mainly driven by mānuka, a widespread shrub species with dense branching, native to New Zealand, Tasmania and south-eastern Australia (Thompson 1989) that is absent from the upper areas of Black Rock Reserve. Instead, the most obvious expanding shrub species at the Black Rock Reserve is D. longifolium, a somewhat rare species in the Glendhu tussock catchment. Mānuka is known to be an effective invasive species, in part because of its ability to become rapidly established in grassland and eventually overtop it (Chapman \& Bannister 1990). It is responsible for woody expansion in grasslands in other regions of New Zealand (Roger \& Leathwick 1996) and in south-eastern Australia (Price \& Morgan 2009). Based on dendrochronological analysis, Roger \& Leathwick (1996) showed a continuous increase in the cover of this species over a 75-year period in various combinations of slopes, topography and elevation in North Island montane tussock grasslands. The persistence and spread of mānuka in these grassland landscapes may have been facilitated by frequent past burning that reduced the abundance of broadleaved forest trees and maintained a relatively open, mixed, tall and short tussock grassland. The long Holocene fire history in the study area is supported by the presence of both serotinous and non-serotinous individuals of mānuka (Battersby et al. 2017a).

\section{Heterogeneity at the catchment scale and implication for future shrub cover increase}

The contrasting performance of shrub species across the landscape could limit, or at least slow down further woody cover increase in the tussock catchment. Shrub cover has increased by $29 \%$ in a 35 -year period $(0.83 \%$ per year), and consequently, at this rate, shrubs could potentially cover the entire catchment by c. 2090 . It is however unlikely that this rate will remain constant in future, as our results show a clear impact of elevation, slope and aspect on shrub cover increase at the catchment scale. While extensive increase in shrub cover has been observed to date in and around gullies, hilltops remained relatively devoid of shrubs. Such interpretation is consistent with a study conducted in the Tongariro National Park, on the North Island of New Zealand, where woody species such as mānuka appear to be much more competitive at lower elevation and on steeper slopes, whereas herbaceous species dominated on flat to gentle slopes over a 75-year period (Roger \& Leathwick 1996). It also corroborates the Black Rock Reserve monitoring study, where mānuka was absent from high elevation grasslands ( $>700 \mathrm{~m}$ a.s.l.; Mark \& Dickinson 2003), and the Campbell Island study, where another shrub species expanded at different rates across the landscape (Wilmshurst et al. 2004). All these results suggest that shrub species, such as mānuka, are able to increase in abundance following changes to the disturbance regime, but only in sites located on steep slopes or at low elevation. On flat and boggy terrains with dense grass cover such as hilltops, shrubs appear to have difficulties in replacing herbaceous species. This assumption is supported by the low frequency of shrub recruits observed in the field above general shrubline, but would merit further investigation. Shrub cover increase was also more important on north and east facing slopes, a pattern that could be explained by the positive effect of warmer soils and greater insolation on mānuka performance. In the study region, increased temperatures has been linked to higher germination rates for mānuka (Battersby et al. 2017b), and could in part explain the discrepancy in cover increase between north/east and south/west facing slopes. Differences in grazing intensity between slope aspects is unlikely, as the catchment is fenced and herbivory is thought to be low throughout the catchment. 


\section{Implications}

Eldridge et al. (2011) showed that the impacts of encroaching woody species on ecosystem dynamics is species- and sitespecific. In New Zealand, grasslands have been maintained by human activities over the last centuries (McGlone \& Wilmshurst 1999), and the increase in shrub cover could be a first step toward the recovery of a forested ecosystem. Whether or not indigenous tree species will recolonize the study area will however depend on different factors, including the distance to seed sources. In the meantime, maintaining a mosaic of grasslands and shrublands at the landscape scale can sustain complementary indigenous species resulting in greater overall species richness for plants, invertebrates and birds (Walker et al. 2014b). Elsewhere however, tall shrub species are more likely to impact the structure and functions of the ecosystem they encroach, but the magnitude and direction of these impacts depend on other environmental conditions. For example, the shade provided by tall shrubs may promote facilitation in drylands through the reduction of soil evaporation (Maestre et al. 2003), but rainfall interception by tall and dense shrub canopies could also reduce available soil moisture in areas where rainfall is limited (Bellot et al. 2004). With its tall stature and dense branching, mānuka has the potential to impact ecosystem services from indigenous grasslands. Expansion of mānuka in herb-rich woodlands in southeastern Australia has been associated with reduction in plant species richness, in ground-layer biomass and in soil seed bank (Price \& Morgan 2008).

An increase in shrub cover in a tussock water catchment also has the potential to reduce water yield, as has been observed for afforestation of grasslands in many regions of the world (Farley et al. 2005). The small but steady reduction in water yield registered from 1980 to 2013 in the Glendhu tussock water catchment (Fahey et al. 2017) could in part be caused by the cumulative increase in shrub cover we observed in our study. Shrubs have more similarity to trees than grasses in terms of total root biomass and maximum rooting depth (Jackson et al. 1996). Moreover, shrubs have a longer active transpiration period than seasonally dormant grasses and their contribution to annual transpiration is more likely to be similar to that of trees (Farley et al. 2005). As a result, afforestation had a greater impact in water yield for grasslands than for shrublands in different regions worldwide (Farley et al. 2005). On the other hand, McGlone and Wilmshurst (1999) suggested that the initial destruction of the forest in the Glendhu region did not alter the water yield. This contrasting result could be explained by different transpiration rates between the Lophozonia-dominated forest covering the region before Māori fires and the current pine plantation (Fahey \& Rowe 1992). In New Zealand and elsewhere, shrub expansion in grasslands could have implications for water yields, especially in eastern catchments were precipitation is anticipated to decline and temperatures increase under most climate change predictions (IPCC 2013).

\section{Conclusion}

This research demonstrates a clear increase in shrub cover in a grassland catchment in eastern Otago, New Zealand, over a 35 -year period. Our analysis revealed highly clustered shrub cover change centered on gullies, leaving flat terrains such as hilltops almost free of shrubs. The extensive ground truthing strongly suggests that mānuka, was the main species implicated in the recent shrub succession. Differences in topography across the landscape were found to promote differences in woody cover change, steeper slopes facing north and east at low elevation promoting larger increases in shrub cover. Further studies are now needed to determine the potential future rate of shrub cover change in New Zealand grassland ecosystems, as this phenomenon could have strong implications for biodiversity and water supply, as well as carbon storage and other ecosystem services.

\section{Acknowledgements}

This research was funded by Natural Sciences and Engineering Research Council of Canada (NSERC) and by the Fonds de Recherche Québec - Nature et Technologies (FRQNT). The authors are grateful to Stella Belliss for her valuable help with aerial image analyses and to Emilie Saulnier-Talbot for linguistic revision. We also thank the current land owners, Rayonier New Zealand (Matariki Forests), and especially Steve Chandler for enabling access to the study site.

\section{References}

Adeel Z 2008. Findings of the Global Desertification Assessment by the Millennium Ecosystem Assessment-A perspective for better managing scientific knowledge. In: Lee C, Schaaf, T eds. Future of drylands. Paris, UNESCO. Pp. 677-685.

Ansley RJ, Ben Wu X, Kramp BA 2001. Observation: Longterm increases in mesquite canopy cover in a North Texas savanna. Journal of Range Management 54: 171-176.

Archer SR 2010. Rangeland conservation and shrub encroachment: new perspectives on an old problem. In: Toit JTd, Kock R, Deutsch JC eds. Wild rangelands: Conserving wildlife while maintaining livestock in semiarid ecosystems. Chichester, John Wiley and Sons Ltd. Pp. 53-97.

Augustine DJ, McNaughton SJ 2010. Regulation of shrub dynamics by native browsing ungulates on East African rangeland. Journal of Applied Ecology 41: 45-58.

Battersby PF, Wilmshurst JM, Curran TJ, McGlone MS, Perry GLW 2017a. Exploring fire adaptation in a land with little fire: serotiny in Leptospermum scoparium (Myrtacea). Journal of Biogeography 44: 1306-1318.

Battersby PF, Wilmshurst JM, Curran TJ, Perry GLW 2017 b. Does heating stimulate germination in Leptospermum scoparium (mānuka; Myrtaceae)? New Zealand Journal of Botany 55: 452-465.

Bellot J, Maestre FT, Chirino E, Hernandez N, de Urbina JO 2004. Afforestation with Pinus halepensis reduces native shrub performance in a Mediterranean semiarid area. Acta Oecologia 25: 7-15.

Burnham KP, Anderson DR 2002. Model selection and multimodel inference: a practical information-theoric approach. 2nd edn. New York, Springer. 488 p.

Calder JA, Wilson JB, MarkAF, Ward G 1992. Fire, succession and reserve management in a New Zealand snow tussock grassland. Biological Conservation 62: 35-45.

Chapin FS, Sturm M, Serreze MC, McFadden JP, Key JR, Lloyd AH, McGuire AD, Rupp TS, Lynch AH, Schimel JP, Beringer J, Chapman WL, Epstein HE, Euskirchen ES, Hinzman LD, Jia G, Ping CL, Tape KD, Thompson CDC, Walker DA, Welker JM 2005. Role of land-surface 
changes in Arctic summer warming. Science 310: 657-660. Chapmann HM, Bannister P 1990. The spread of heather, Calluna vulgaris, into indigenous plant communities of Tongariro National Park. New Zealand Journal of Ecology 14: 7-16.

Christensen RHB 2015. Package 'ordinal': regression models for ordinal data, version 2015.6-28. https://cran.r-project. org/web/packages/ordinal/ordinal.pdf.

Christie KS, Ruess RW, Lindberg MS, Mulder CP 2014. Herbivores influence the growth, reproduction, and morphology of a widespread Arctic willow. Plos One 9: e101716.

Dale MRT, Fortin MJ 2002. Spatial autocorrelation and statistical tests in ecology. Ecoscience 9: 162-167.

D’Odorico P, Okin GS, Bestelmeyer BT 2012. A synthetic review of feedbacks and drivers of shrub encroachment in arid grasslands. Ecohydrology 5: 520-530.

Eldridge DJ, Bowker MA, Maestre FT, Roger E, Reynolds JF, Whitford WG 2011. Impacts of shrub encroachment on ecosystem structure and functioning: towards a global synthesis. Ecology Letters 14: 709-722.

Elmendorf SC, Henry GHR, Hollister RD, Bjork RG, Bjorkman AD, Callaghan TV, Collier LS, Cooper EJ, Cornelissen JHC, Day TA, Fosaa AM, Gould WA, Gretarsdottir J, Harte J, Hermanutz L, Hik DS, Hofgaard A, Jarrad F, Jonsdottir IS, Keuper F, Klanderud K, Klein JA, Koh S, Kudo G, Lang SI, Loewen V, May JL, Mercado J, Michelsen A, Molau U, Myers-Smith IH, Oberbauer SF, Pieper S, Post E, Rixen C, Robinson CH, Schmidt NM, Shaver GR, Stenstrom A, Tolvanen A, Totland O, Troxler T, Wahren CH, Webber PJ, Welker JM, Wookey PA 2012. Global assessment of experimental climate warming on tundra vegetation: heterogeneity over space and time. Ecology Letters 15: 164-75.

Fahey BD, WatsonAJ 1991. Hydrological impacts of converting tussock grassland to pine plantation, Otago, New Zealand. Journal of Hydrology - New Zealand 30: 1-15.

Fahey BD, Rowe LK 1992. Land-use impacts. In: Mosley MP ed. Waters of New Zealand. Wellington, Hydrological Society. Pp. 265-284.

Fahey BD, Payne J 2015. Report on the Glendhu Experimental Catchments: 1980-2013. Lincoln, Landcare Research. $65 \mathrm{p}$.

Fahey BD, Payne J 2017. The Glendhu experimental catchment study, upland east Otago, New Zealand: 34 years of hydrological observations on the afforestation of tussock grasslands. Hydrological Processes 31: 2921-2934.

Farley KA, Jobbagy EG, Jackson RB 2005. Effects of afforestation on water yield: a global synthesis with implications for policy. Global Change Biology 11: 1565-1576.

Fensham RJ, Fairfax RJ, Archer SR 2005. Rainfall, land use and woody vegetation cover change in semi-arid Australian savanna. Journal of Ecology 93: 596-606.

Forbes BC, Macias Fauria M, Zetterberg P2010. RussianArctic warming and "greening" are closely tracked by tundra shrub willows. Global Change Biology 16: 1542-1554.

Ghersa CM, de la Fuente E, Suarez S, Leon RJC 2002. Woody species invasion in the Rolling Pampa grasslands, Argentina. Agriculture Ecosystems and Environment 88: 271-278.

Gibbens RP, McNeely RP, Havstad KM, Beck RF, Nolen B 2005. Vegetation changes in the Jornada Basin from 1858 to 1998. Journal of Arid Environments 61: 651-668.
Goslee SC, Havstad KM, Peters DPC, Rango A, Schlesinger WH 2003. High resolution images reveal rate and pattern of shrub encroachment over six decades in New Mexico, USA. Journal of Arid Environments 54: 755-767.

Hallinger M, Manthey, M, Wilmking M 2010. Establishing a missing link: warm summers and winter snow cover promote shrub expansion into alpine tundra in Scandinavia. New Phytologist 186: 890-899.

Hugues L 2003. Climate change and Australia: trends, projections and impacts. Austral Ecology 28: 423-443.

IPCC 2013. Climate change 2013: The physical science basis. Cambridge, Cambridge University Press. 1552 p.

Jackson RB, Canadell J, Ehleringer JR, Mooney HA, Sala OE, Schulze ED 1996. A global analysis of root distributions for terrestrial biomes. Oecologia 108: 389-411.

Jeltsch F, Milton SJ, Dean WRJ, Rooyen NV 1997. Analysing shrub encroachment in the southern Kalahari: a gridbased modelling approach. Journal of Applied Ecology 34: 1497-1508.

Johnson JB, Omland KS 2004. Model selection in ecology and evolution. Trends in Ecology and Evolution 19: 101-108.

KnappAK, Briggs JM, Collins SL, Archer SR, Bret-Harte MS, Ewers BE, Peters DP, Young DR, Shaver GR, Pendall E, Cleary MB 2008. Shrub encroachment in North American grasslands: shifts in growth form dominance rapidly alters control of ecosystem carbon inputs. Global Change Biology 14: 615-623.

Leathwick J, McGlone MS, Walker S, Briggs C 2004. New Zealand's potential vegetation pattern. Lincoln, Manaaki Whenua-Landcare Research. 16 p.

Lett MS, Knapp AK 2005. Woody plant encroachment and removal in mesic grassland: production and composition responses of herbaceous vegetation. American Midland Naturalist 153: 217-231.

Li J, Okin GS, Hartman LJ, Epstein HE 2007. Quantitative assessment of wind erosion and soil nutrient loss in desert grasslands of southern New Mexico, USA. Biogeochemistry 85: 317-332.

Li J, Okin GS, Alvarez LJ, Epstein HE 2008. Effects of wind erosion on the spatial heterogeneity of soil nutrients in two desert grassland communities. Biogeochemistry 88: 73-88.

Liston GE, McFadden JP, Sturm M, Pielke RA2002. Modelled changes in arctic tundra snow, energy and moisture fluxes due to increased shrubs. Global Change Biology 8: 17-32.

Maestre FT, Bautista S, Cortina J 2003. Positive, negative, and net effects in grass-shrub interactions in Mediterranean semiarid grasslands. Ecology 84: 3186-3197.

Maestre FT, Bowker MA, Puche MD, Hinojosa MB, Martinez I, Garcia-Palacios P, Castillo AP, Soliveres S, Luzuriaga, Sanchez AM, Carreira JA, Gallardo A, Escudero A 2009. Shrub encroachment can reverse desertification in semi-arid Mediterranean grasslands. Ecology Letters 12: $930-41$.

Mark AF, Dickinson KJM 2003. Temporal responses over 30 years to removal of grazing from a mid-altitude snow tussock grassland reserve, Lammerlaw Ecological Region, New Zealand. New Zealand Journal of Botany 41: 655-668.

Mark AF, Dickinson KJM 2008. Maximizing water yield with indigenous non-forest vegetation: a New Zealand perspective. Frontiers in Ecology and the Environment 6: 25-34.

Marsh P, Bartlett P, MacKay M, Pohl S, LantzT2010. Snowmelt energetics at a shrub tundra site in the western Canadian 
Arctic. Hydrological Processes 24: 3603-3620.

Mazerolle MJ 2006. Improving data analysis in herpetology: using Akaike's Information Criterion (AIC) to assess the strength of biological hypotheses. Amphibia-Reptilia 27: $169-180$.

Mazerolle MJ 2014. Package 'AICcmodavg', version 2.1-1. http://cran.rproject.org/web/packages/AICcmodavg/ AICcmodavg.pdf.

McGlone MS 2001. The origin of the indigenous grasslands of southeastern South Island in relation to pre-human woody ecosystems. New Zealand Journal of Ecology 25: 1-15.

McGlone MS, Wilmhurst JM 1999. A Holocene record of climate, vegetation change, and peat bog development, east Otago, South Island, New Zealand. Journal of Quaternary Science 14: 239-254.

McGlone MS, Wilmshurst JM, Meurk CD 2007. Climate, fire, farming and the recent vegetation history of subantarctic Campbell Island. Earth \& Environmental Science Transactions of the Royal Society of Edinburgh 98: 71-84.

McKinley DC, Blair JM 2008. Woody plant encroachment by Juniperus virginiana in a mesic native grassland promotes rapid carbon and nitrogen accrual. Ecosystems 11: 454-468.

Morgan JA, Milchunas DG, LeCain DR, West M, Mosier AR 2007. Carbon dioxide enrichment alters plant community structure and accelerates shrub growth in the shortgrass steppe. Proceeding of the National Academy of Science of the United States of America 104: 14724-14729.

Myers-Smith H, Forbes BC, Wilmking M, Hallinger M, Lantz T, Blok D, Tape KD, Macias-Fauria M, Sass-Klaassen U, Levesque E, Boudreau S, Ropars P, Hermanutz L, Trant A, Collier LS, Weijers S, Rozema J, Rayback SA, Schmidt NM, Schaepman-Strub G, Wipf S, Rixen C, Menard CB, Venn S, Goetz S, Andreu-Hayles L, Elmendorf S, Ravolainen V, Welker J, Grogan P, Epstein HE, Hik DS 2011. Shrub expansion in tundra ecosystems: dynamics, impacts and research priorities. Environmental Research Letter 6: 1-15.

Myers-Smith IH, Elmendorf SC, Beck PSA, Wilmking M, Hallinger M, Blok D, Tape KD, Rayback SA, MaciasFauria M, Forbes BC, Speed JDM, Boulanger-Lapointe N, Rixen C, Levesque E, Schmidt NM, Baittinger C, Trant AJ, Hermanutz L, Collier LS, Dawes MA, Lantz TC, Weijers S, Jorgensen RH, Buchwal A, Buras A, Naito AT, Ravolainen V, Schaepman-Strub G, Wheeler JA, Wipf S, Guay KC, Hik DS, Vellend M 2015. Climate sensitivity of shrub growth across the tundra biome. Nature Climate Change 5: 887-891.

Naito AT, Cairns DM 2011. Patterns and processes of global shrub expansion. Progress in Physical Geography 35: 423-442.

O’Loughlin CL, Rowe LK, Pearce AJ 1984. Hydrology of mid-altitude tussock grasslands, upper Waipori catchment, Otago: I - Erosion, sediment yield and water quality. Journal of Hydrology New Zealand 23: 45-49.

Olofsson J, Oksanen L, Callaghans T, Hulme PE, Oksanen $\mathrm{T}$, Suominen O 2009. Herbivores inhibit climate-driven shrub expansion on the tundra. Global Change Biology 15: 2681-2693.

Pacala SW, Hurtt GC, Baker D, Peylin P, Houghton RA, Birdsey RA, Heath L, Sundquist ET, Stallard RF, Ciais P, Moorcroft P, Caspersen JP, Shevliakova E, Moore B, Kohlmaier G, Holland E, Gloor M, Harmon ME, Fan SM, Sarmiento JL, Goodale CL, Schimel D, Field CB 2001.
Consistent land- and atmosphere-based US carbon sink estimates. Science 292: 2316-2320.

Parsons AJ, Abrahams AD, Wainwright J 1996. Responses of interrill runoff and erosion rates to vegetation change in southern Arizona. Geomorphology 14: 311-317.

Peters DPC, Yao J, Gosz JR 2006. Woody plant invasion at a semi-arid/arid transition zone: Importance of ecosystem type to colonization and patch expansion. Journal of Vegetation Science 17: 389-396.

Pomeroy JW, Bewley DS, Essery RLH, Hedstrom NR, Link T, Granger RJ, Sicart JE, Ellis CR, Janowicz JR 2006. Shrub tundra snowmelt. Hydrological Processes 20: 923-941.

Price JN, Morgan JW 2008. Woody plant encroachment reduces species richness of herb-rich woodlands in southern Australia. Austral Ecology 33: 278-289.

Price JN, Morgan JW 2009. Multi-decadal increases in shrub abundance in non-riverine red gum (Eucalyptus camaldulensis) woodlands occur during a period of complex land-use history. Australian Journal of Botany 57: $163-170$.

RatajczakZ, Nippert JB, Collins SL 2012. Woody encroachment decreases diversity across North American grasslands and savannas. Ecology 93: 697-703.

Roger GM, Leathwick JR 1996. North Island seral tussock grasslands 2. Autogenic succession: change of tussock grassland to shrubland. New Zealand Journal of Botany 32: 287-303.

Ropars P, Boudreau S 2012. Shrub expansion at the foresttundra ecotone: spatial heterogeneity linked to local topography. Environmental Research Letters 7: 015501.

Ropars P, Lévesque E, Boudreau S 2015. How do climate and topography influence the greening of the forest-tundra ecotone in northern Québec? A dendrochronological analysis of Betula glandulosa. Journal of Ecology 103: 679-690.

Roques KG, O’Connor TG, Watkinson AR 2001. Dynamics of shrub encroachment in an African savanna: relative influences of fire, herbivory, rainfall and density dependence. Ecology 38: 268-280.

Sala OE, Maestre FT 2014. Grass-woodland transitions: determinants and consequences for ecosystem functioning and provisioning of services. Journal of Ecology 102: 1357-1362.

Schlesinger WH, Abrahams AD, Parsons AJ, Wainwright J 1999. Nutrient losses in runoff from grassland and shrubland habitats in Southern New Mexico: Rainfall simulation experiments. Biogeochemistry 45: 21-34.

Skowno AL, Thompson MW, Hiestermann J, Ripley B, West AG, Bond WJ 2017. Woodland expansion in South African grassy biomes based on satellite observations (1990-2013): general patterns and potential drivers. Global Change Biology 23: 2358-2369.

Sugiura N 1978. Further analysis of the data by Akaike's information criterion and the finite corrections. Communications in Statistics - Theory and Methods A7: $13-26$.

Tape KD, Sturm M, Racine C 2006. The evidence for shrub expansion in northern Alaska and the pan-Arctic. Global Change Biology 12: 686-702.

Thompson J 1989. Leptospermum. Telopea 3: 302-447.

Trollope WSW, Hobson FO, Danckwerts JE, Van Niekerk JP 1989. Encroachment and control of undesirable plants. In: Danckwerts JE, Van Niekerk JP eds. Veld management in the Eastern Cape. Department of Agriculture and Water 
Supply, Pretoria, South Africa. Pp. 73-89.

Van Auken OW 2000. Shrub invasions of North American semiarid grasslands. Annual Review of Ecology and Systematics 31: 197-215.

Wainwright J, Parsons AJ, Abrahams AD 2000. Plotscale studies of vegetation, overland flow and erosion interactions: case studies from Arizona and New Mexico. Hydrological Processes 14: 2921-2943.

Walker S, Lee WG, \& Rogers GM 2004. The woody vegetation of Central Otago, New Zealand. New Zealand Journal of Botany 42: 589-612.

Walker S, King N, Monks A, Williams S, Burrows L, Cieraad E, Meurk C, Overton JMcC, Price R, Smale M 2009. Secondary woody vegetation patterns in New Zealand's South Island dryland zone. New Zealand Journal of Botany 47: 367-393.

Received 23 November 2017; accepted 10 May 2018

Editorial board member: Matt McGlone
Walker S, Wilson DJ, Norbury G, Monks A, Tanentzap AJ 2014a. Complementarity of indigenous flora in shrublands and grasslands in a New Zealand dryland landscape. New Zealand Journal of Ecology 38: 230-241.

Walker S, Wilson DJ, Norbury G, Monks A, Tanentzap AJ 2014b. Effects of secondary shrublands on bird, lizard and invertebrate faunas in a dryland landscape. New Zealand Journal of Ecology 38: 242-256.

Weeks ES, Walker S, Dymond JR, Shepherd JD, Clarkson BD 2013. Patterns of past and recent conversion of indigenous grasslands in the South Island, New Zealand. New Zealand Journal of Ecology 37: 127-138.

Weltzin JF, Archer S, Heitschmidt RK 1997. Small-mammal regulation of vegetation structure in a temperate savanna. Ecology 78: 751-763.

Wilmshurst JM, Bestic KL, Meurk CD, McGlone MS 2004. Recent spread of Dracophyllum scrub on subantarctic Campbell Island, New Zealand: climatic or anthropogenic origins? Journal of Biogeography 31: 401-413. 